\section{(- OPEN ACCESS}

\title{
Runaway pacemaker
}

\author{
Ambreen Gul, Muhammad Asad Sheikh, Atif Rao
}

Department of Cardiology, Southend University Hospital NHS Foundation Trust, Westcliffon-Sea, UK

\section{Correspondence to Dr Ambreen Gul, ambreen.gul@southend.nhs.uk}

Accepted 7 December 2018

\section{Check for updates}

(C) BMJ Publishing Group Limited 2019. Re-use permitted under CC BY-NC. No commercial re-use. See rights and permissions. Published by BMJ.

To cite: Gul A, Sheikh MA, Rao A. BMJ Case Rep

2019:12:e225411.

doi:10.1136/bcr-2018-

225411

\section{SUMMARY}

Runaway pacemaker is phenomenon in which pacemaker induces ventricular tachycardia as a result of some malfunction in the device. This entity is not very common in clinical practice. Normally, the pacemaker perceives the inherent cardiac impulse and hence averting the delivery of pacemaker stimulus in susceptible period of cardiac cycle. This is a case of a pacemaker-induced tachycardia (named as runaway pacemaker) in a patient with a history of Single Chamber Ventricular (VVI) pacemaker. A 75-year-old man was admitted with 3 days history of fluttering in the chest, shortness of breath, central chest and epigastric pain which radiated to the back. His medical history includes pacemaker implantation in 1996 with lead complication following which he was managed with VVI pacemaker, and the last procedure was generator change 4 years ago with no complication. Examination revealed ventricular tachycardia with ECG showing paced rhythm with ventricular pacing at the rate of $200-150 / \mathrm{min}$. His pacemaker-induced ventricular tachycardia was immediately aborted after putting magnet on the device which restored his baseline rhythm with heart rate of $60 / \mathrm{min}$. Pacemaker was explanted urgently with replacement of new pulse generator. The patient was discharged home with VVI pacemaker showing excellent parameters.

\section{BACKGROUND}

Pacemaker is a cardiac device which delivers stimulus to myocardium in the periods of slow heart rate below the device presetting rate. Pacemaker-induced ventricular tachycardia is an uncommon complication that can happen any time after the implantation of the device. Period may range from a few days to years after the device implantation.

Runaway pacemaker, if happens due to malfunction of the device, results in ventricular tachycardia. This tachycardia cannot be terminated by extrinsic cardioversion or by pharmacological agents because intrinsic device is discharging the continuous impulses with no operational inhibiting system.

Some strategies to overcome this critical condition have been suggested in the literature. Generator reprogramming and use of overstimulation electrode has been mentioned in literature with poor results. Other strategy involves disconnecting the generator electrodes by cutting leads but this may leave with cardiac asystole. The only possible solution is to disinhibit the pacemaker with magnet and urgently implant the temporary or permanent device.

Here we present a case of pacemaker-induced ventricular tachycardia in a patient who had permanent pacemaker implantation in 1996 with lead complication ending up in Single Chamber Ventricular (VVI) pacemaker. The patient had a generator change 4 years ago with no complication. He presented with extreme palpitations and shortness of breath for the last 3 days. His ECG showed a typical right ventricular tachycardia which was preceded by pacemaker spike. Ventricular tachycardia did not resolve by intravenous metoprolol and amiodarone. Finally aborted by putting magnet on the device. The patient had urgent change of pulse generator and normal sensing paced rhythm restored.

\section{CASE PRESENTATION}

A 75 -year-old man was admitted with 3 days history of fluttering in the chest, shortness of breath, central chest and epigastric pain which radiated to the back.

His medical history includes exertional angina, unobstructed coronaries in 2013, hypercholestraemia and single-chamber permanent pacemaker for complete heart block in 1994.

The patient was conscious, and tachycardiac with blood pressure of $100 / 70 \mathrm{~mm} \mathrm{Hg}$. His chest was clear with signs of congestive heart failure.

\section{INVESTIGATIONS}

1. Blood chemistry results showed normal serum sodium, potassium, calcium and magnesium.

2. His cardiac troponin was $>1000$.

3. ECG showed ventricular tachycardia with paced rhythm (figure 1).

4. Pacemaker interrogation showed persistent tachycardia with rate of 189 beats/min for the last 24 hours (figure 2).

5. ECG after termination of ventricular tachycardia showed baseline sinus rhythm with average heart rate of $60 / \mathrm{min}$ (figure 3 ).

6. Echocardiogram showed poor left ventricular systolic function with ejection fraction of $35 \%$.

\section{DIFFERENTIAL DIAGNOSIS}

On the basis of ECG finding, runaway pacemaker (pacemaker-induced ventricular tachycardia) was the most likely diagnosis.

\section{TREATMENT}

The patient was given trial of intravenous metoprolol and amiodarone with no effect.

The pacemaker was disabled with a magnet placed on it which terminated the arrhythmia. $\mathrm{He}$ was urgently transferred to catheterisation lab and 


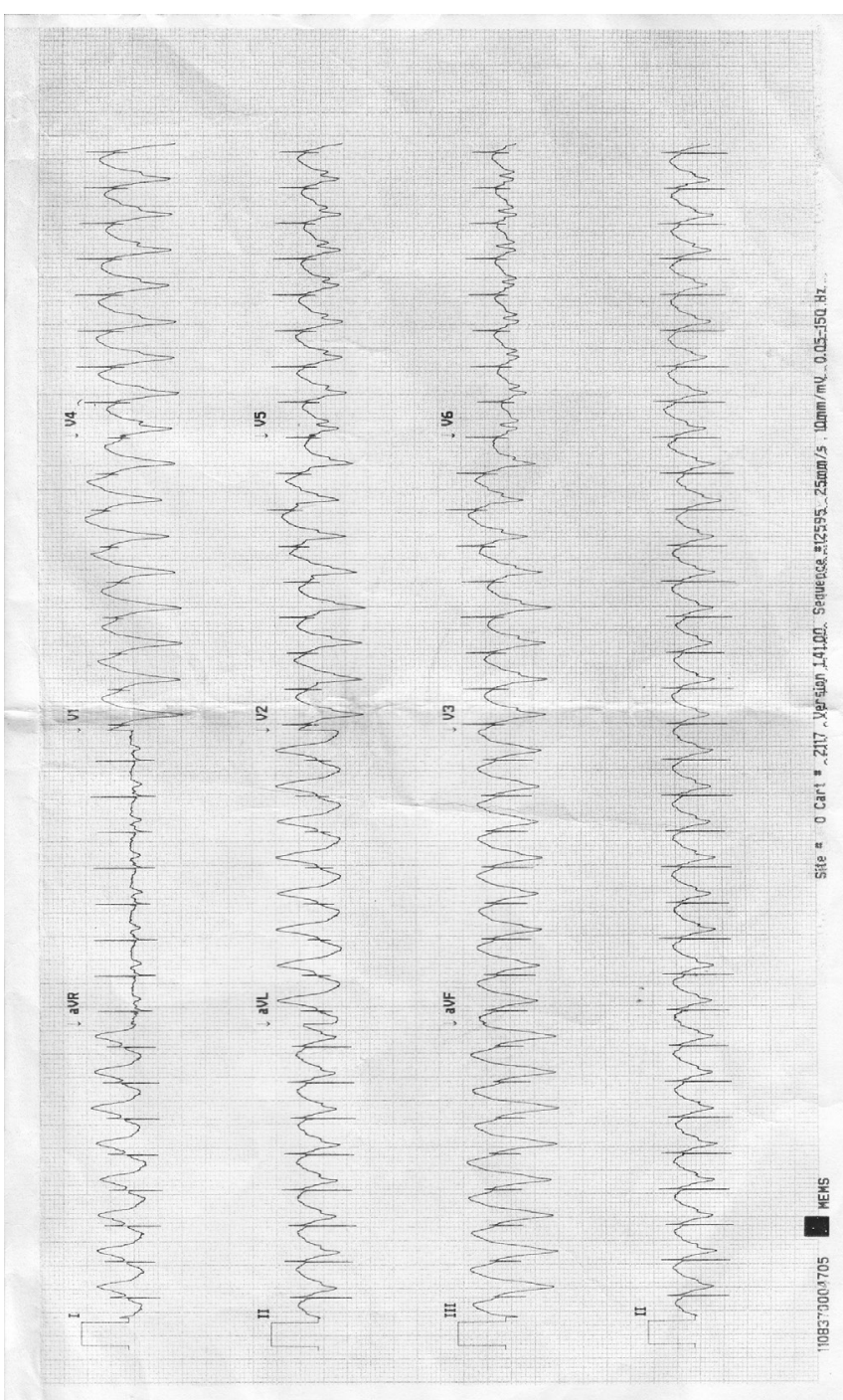

Figure 1 ECG.

pulse generator was replaced with resumption of normal paced rhythm.

\section{OUTCOME AND FOLLOW-UP}

The patient was discharged home in stable condition with excellent pacemaker parameters.

The patient's follow-up echocardiogram improved ejection fraction to almost normal after restoration of heart rate.

\section{DISCUSSION}

Pacemaker-induced ventricular tachycardia has been described in literature. The earliest report was published in 1965 in a patient who had a fixed rate pacemaker inserted. The most probable reason described was electronic failure. ${ }^{1}$ Examination by the manufacturer of the unit used in this case revealed the failure of a transistor in the timing circuit. There was also a 6.4 V direct current leak caused by component failure of the pacemaker output capacitor. This current has been shown to cause polarisation and increased resistance at the positive pole of myocardium.

The fusion of two separate impulses, one arising from pacemaker, the other from ventricular ectopic, is another possible reason described in literature. Ventricular extra systoles occurred

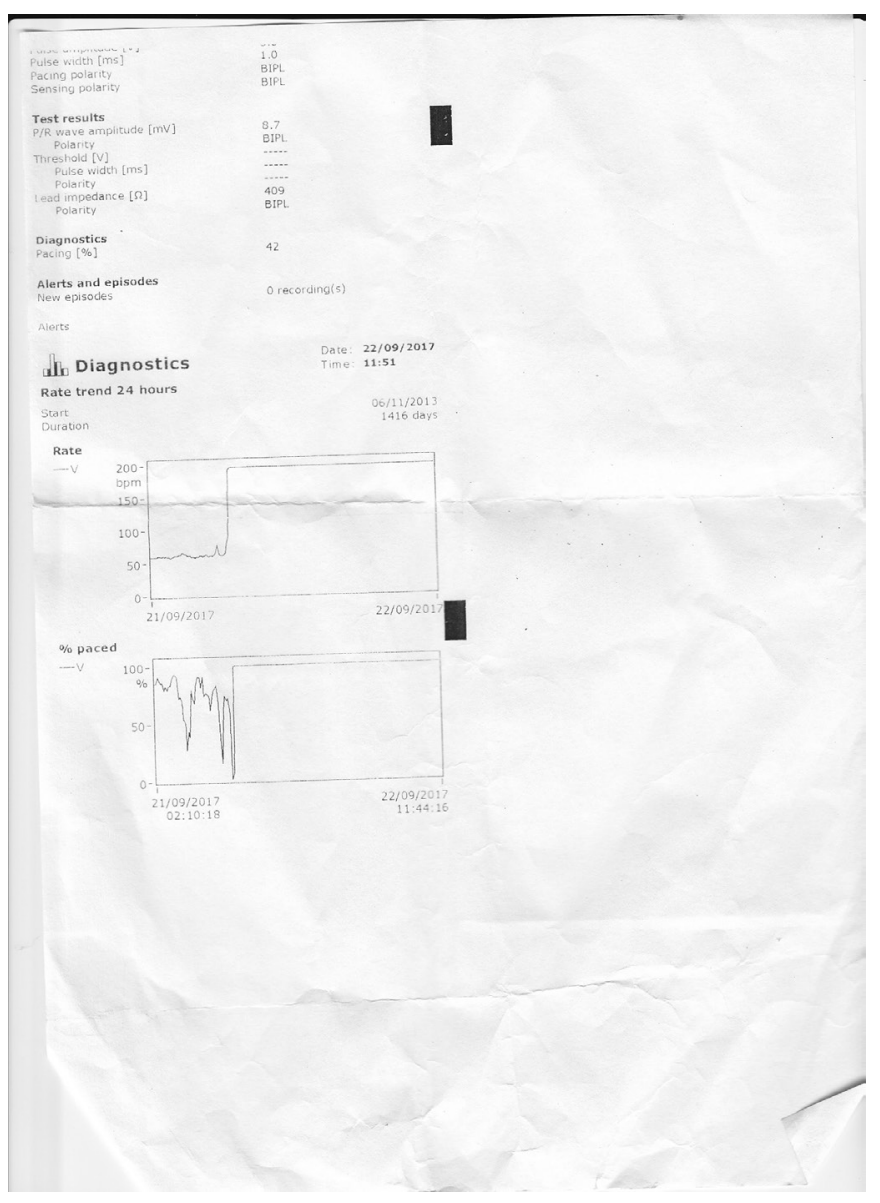

Figure 2 Pacemaker recordings.

at a variable coupling interval of $640-720 \mathrm{~ms}$, and that they were all of similar configuration. Those extra systoles with a short coupling interval (653 (41) ms) inhibited the output of the pacemaker and did not cause ventricular tachycardia. The ventricular extra systoles with a long coupling interval that was close to the programmed cycle length of the pacemaker (710 (14) vs $732 \mathrm{~ms}$ ) failed to inhibit the pacemaker output, presumably because depolarisation from the extra systole had not spread to the pacemaker electrode site in time to inhibit the pacemaker. The resulting fusion beat usually triggered ventricular tachycardia. ${ }^{2}$

Other possible cause mentioned in the literature is atrial sensing during postventricular refractory period eliciting ineffective atrial stimulation. The following native ventricular beat cannot be identified by the device because it occurred during

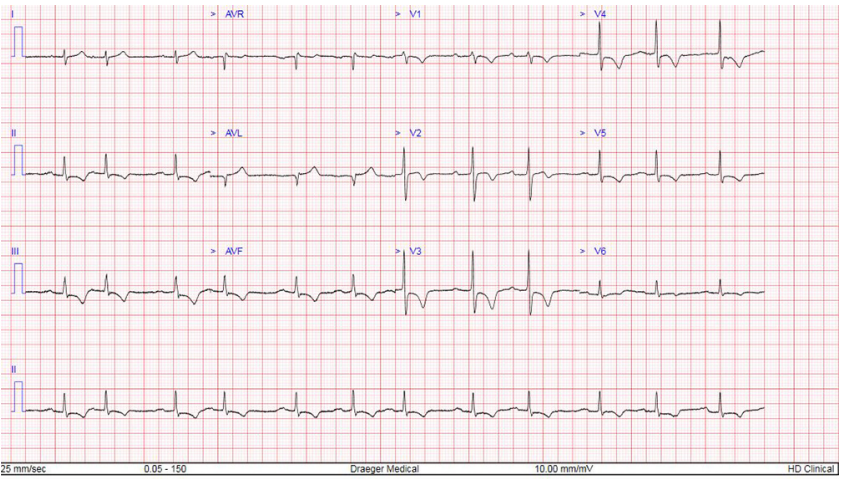

Figure 3 ECG after turning off the pacemaker. 
cross-chamber blanking period. As a result, after atrioventricular delay, ventricular pacing artefact is delivered inducing fatal ventricular tachycardia. ${ }^{3}$

\section{Learning points}

- Pacemaker-induced ventricular tachycardia is an emergency which needs to be addressed urgently.

- Patients with this particular type of ventricular tachycardia would not respond to any medical treatment or cardioversion as fault lies in pacemaker.

- These patients need to disable the device via magnet and urgent change of pulse generator.

- Recognition of this phenomenon is vital as mostly patients present in emergency room with symptoms or collapse.

Correction notice Since this article was first published online, figure 1 has been replaced.

Acknowledgements Mrs Karen Cousins, Senior Cardiac Physiologist (Southend University Hospital NHS Foundation Trust), contributed towards completion of this report by providing pacemaker recordings. She is not in the authors list.
Contributors $A G$ is the main author who prepared the patient summary, reviewed the literature and complied the whole case into format. She gained access to BMJ Case Report and resubmitted the article after correcting the errors. MAS contributed with the ECG and laboratory data acquisition. AR contributed towards obtaining the consent of the patient.

Funding The authors have not declared a specific grant for this research from any funding agency in the public, commercial or not-for-profit sectors.

Competing interests None declared.

Patient consent for publication Not required.

Provenance and peer review Not commissioned; externally peer reviewed.

Open access This is an open access article distributed in accordance with the Creative Commons Attribution Non Commercial (CC BY-NC 4.0) license, which permits others to distribute, remix, adapt, build upon this work non-commercially, and license their derivative works on different terms, provided the original work is properly cited and the use is non-commercial. See: http://creativecommons.org/ licenses/by-nc/4.0/

\section{REFERENCES}

1 Wisoff BG, Wisoff MD. Pacemaker-induced ventricular tachycardia. JAMA 1965;192:258.

2 Lefroy DC, Crake T, Davies DW. Ventricular tachycardia: an unusual pacemaker-mediated tachycardia. Br Heart J 1994;71:481-3.

3 Oxford Academic. Vogelgesange, Pacemaker-induced ventricular tachycardia. EP Europace 2008;10:46-7.

Copyright 2019 BMJ Publishing Group. All rights reserved. For permission to reuse any of this content visit

https://www.bmj.com/company/products-services/rights-and-licensing/permissions/

BMJ Case Report Fellows may re-use this article for personal use and teaching without any further permission.

Become a Fellow of BMJ Case Reports today and you can:

- Submit as many cases as you like

- Enjoy fast sympathetic peer review and rapid publication of accepted articles

- Access all the published articles

Re-use any of the published material for personal use and teaching without further permission

\section{Customer Service}

If you have any further queries about your subscription, please contact our customer services team on +44 (0) 2071111105 or via email at support@bmj.com.

Visit casereports.bmj.com for more articles like this and to become a Fellow 